\title{
Modeling of Pulverized Coal Combustion in Cement Rotary Kiln
}

\author{
Shijie Wang, ${ }^{\dagger}$ Jidong Lu,,${ }^{\dagger}$ Weijie $\mathrm{Li},{ }^{\dagger} \mathrm{Jie} \mathrm{Li}^{\dagger}{ }^{\dagger}$ and $\mathrm{Zhijuan} \mathrm{Hu}^{\ddagger}$ \\ State Key Laboratory of Coal Combustion, Huazhong University of Science and Technology, \\ Wuhan, 430074, Hubei Province, People's Republic of China, and Tianjin Cement Industry Design \& \\ Research Institute, Tianjin, 300400, People's Republic of China \\ Received January 19, 2006. Revised Manuscript Received April 22, 2006
}

\begin{abstract}
In this paper, based on analysis of the chemical and physical processes of clinker formation, a heat flux function was introduced to take account of the thermal effect of clinker formation. Combining the models of gas-solid flow, heat and mass transfer, and pulverized coal combustion, a set of mathematical models for a full-scale cement rotary kiln were established. In terms of commercial CFD code (FLUENT), the distributions of gas velocity, gas temperature, and gas components in a cement rotary kiln were obtained by numerical simulation of a $3000 \mathrm{t} / \mathrm{d}$ rotary kiln with a four-channel burner. The predicted results indicated that the improved model accounts for the thermal enthalpy of the clinker formation process and can give more insight (such as fluid flow, temperature, etc, ) from within the cement rotary kiln, which is a benefit to better understanding of combustion behavior and an improvement of burner and rotary kiln technology.
\end{abstract}

\section{Introduction}

In the modern cement industry, the rotary kiln is key equipment widely used to produce cement clinker. To meet the requirement of the design and optimization of a cement rotary kiln, there is an urgent need to understand detailed processes in a rotary kiln. Mathematical modeling can give more insight, such as the distributions of gas-solid flow, temperature, and composition of gas and particles within a rotary kiln. Modeling of the process has achieved more success in many industrial fields, such as cement precalciner, rotary lime kiln, etc. ${ }^{1,2}$ But so far very few expressions have existed for the processes in a cement rotary kiln, which include fuel combustion, heat transfer, and clinker chemistry. One of important reasons is the complexity of heat transfer that takes place simultaneously with chemical, physical, and mineralogical reactions. In addition, the in-site measurements for the detailed physical parameters to investigate the processes are complicated and are not possible yet in many cases.

Nevertheless, some aspects of the processes taking place in the cement rotary kiln have been investigated individually in the past. ${ }^{3-5}$ Ghoshdastidar and Anandan Unni presented a steady-state heat transfer model used for drying and preheating of wet solids with application to nonreacting zone of a cement rotary kiln. ${ }^{6}$ The zone method and the Monte Carlo method were used for calculating the radiative heat transfer within the dry process and the wet process in a cement rotary kiln. ${ }^{7}$ The

\footnotetext{
* Corresponding author. E-mail: jdlu@mail.hust.edu.cn.

Huazhong University of Science and Technology.

$\doteqdot$ Tianjin Cement Industry Design \& Research Institute.

(1) Lu, J. D.; Huang, L.; Hu Z. J.; Wang, S. J. Simulation of the gassolid two-phase flow, coal combustion and raw meal calcination in a precalciner. ZKG Int. 2004, 57 (2), 55-63.

(2) Georgallis, M.; Nowak, P.; Salcudean, M. Modelling the rotary lime kiln. Can. J. Chem. Eng. 2005, 83 (2), 212-223.

(3) Khraisha, Y. H.; Dugwell, D. R. Thermal decompostion of limestone in a suspension reactor. Chem. Eng. Res. Des. 1989, 67, 52-57.

(4) Khraisha, Y. H.; Dugwell, D. R. Coal combustion and limestone calcination in suspension reactor. Chem. Eng. Sci. 1992, 47 (5), 993-1006.

(5) Carvalho, M. G.; Farias, T.; Martins, A. Three-dimensional modelling of the radiative heat transfer in a cement kiln. Conduction, Radiation and Phase Change; Computational Mechanics Inc: Billerica, MA, 1992; pp $141-160$.
}

chemical reactions that take place during clinker formation, however, were not taken into account, and the temperature of the gas phase was fixed at a uniform value.

The formation processes of the clinker phases include a series of individual reactions. Although some efforts have been made to investigate the process, there still exist many uncertainties, especially sintering. The kinetic process of the clinker has not been well understood up to now. The technique of thermochemical process simulation has been used to compile a model that enables the chemical reactions to be calculated in various process stages (preheater, calcinatory, rotary kiln divided into the transition zone and sintering zone, cooler) ${ }^{8}$ Locher assumed that the conversion ratio of material is linearly dependent on the final temperature at the range between the minimum temperature and the limiting temperature; the reaction kinetics was not accounted for. ${ }^{9,10}$ Some researchers neglected the complication of mineralogical reactions and assumed that chemical reaction models in the kiln consisted of a few simplified reactions, and the according kinetic parameters were adopted from some literature. 7,11

Combustion behavior of fuel was widely studied because it supplied enough energy to meet the heat requirement in a rotary kiln. Mathematic models of coal combustion have made better progresses in other fields. However, modeling of coal combustion for a cement rotary kiln was mostly carried out in the burning zone close to the burner and did not account for the

(6) Ghoshdastidar, P. S.; Anandan Unni, V. K. Heat transfer in the nonreacting zone of a cement rotary kiln. J. Eng. Ind., Trans. ASME 1996, 118 (1), 169-171.

(7) Guruz, H. K.; Bac, N. Mathematical modeling of rotary cement kiln by the zone method. Can. J. Chem. Eng. 1981, 59 (4), 540-548.

(8) Modigell, M.; Liebig D.; Munstermann, S. Calculation of the clinker burning process using thermochemical process simulation. ZKG Int. 2002, 55 (7), 38-46.

(9) Locher, G. Mathmatical models for the cement clinker burning process. Part 1: Reactions and unit operations. ZKG Int. 2002, 55 (1), 2938 .

(10) Locher, G. Mathmatical models for the cement clinker burning process. Part 2: Rotary kiln. ZKG Int. 2002, 55 (3), 68-80.

(11) Mastorakos, E.; Massias, A.; Tsakiroglou, C. D. CFD predictions for cement kilns including flame modelling, heat transfer and clinker chemistry. Appl. Math. Modell. 1999, 23 (1), 55-76. 


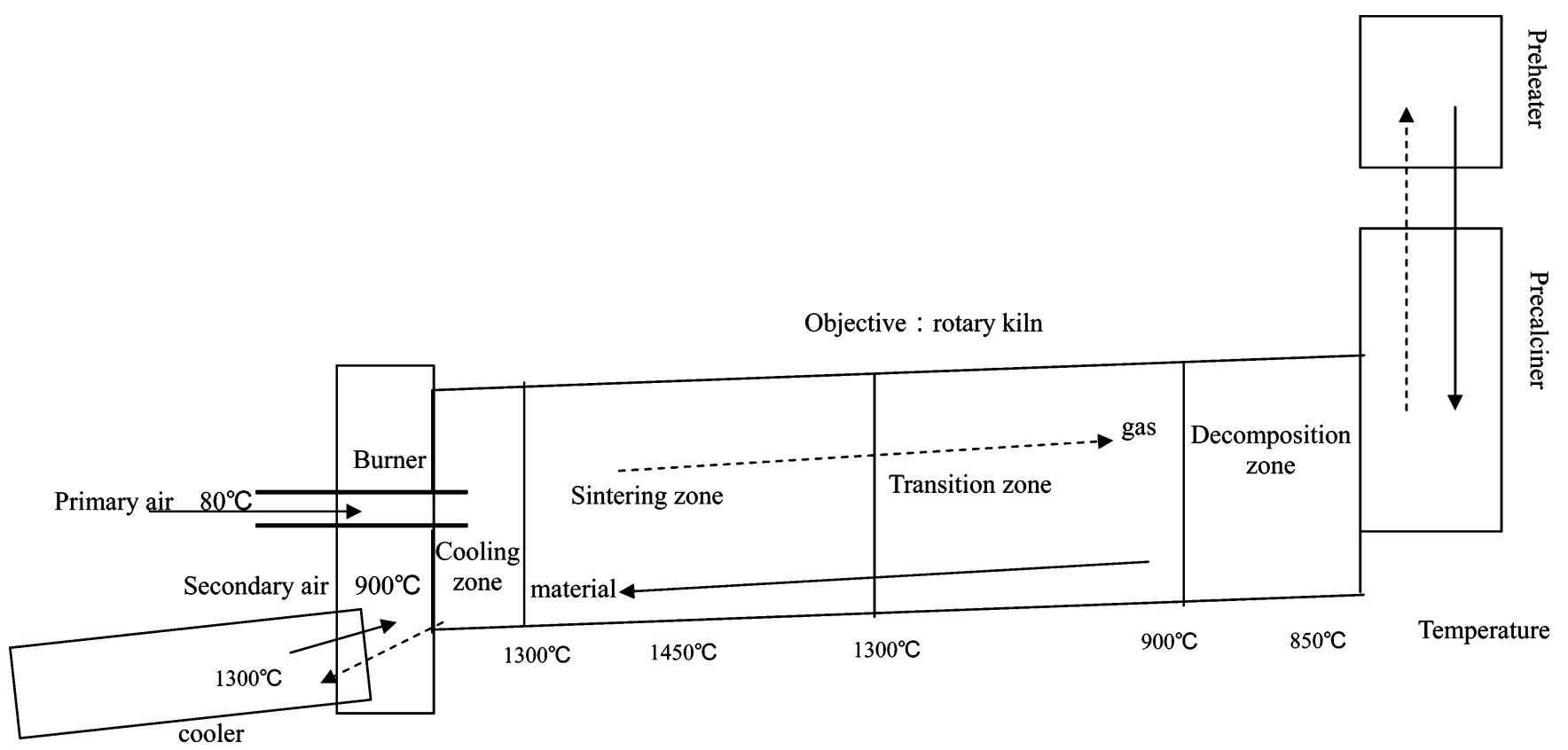

Figure 1. Abridged general view of modern dry process cement rotary kiln system.

effects of the clinker formation process, which influences the temperature of gas phase. ${ }^{12-14}$

On the basis of the above theoretical models, some investigators have combined those models to form a complete model so that certain information of processes in rotary kilns can be understood. Locher obtained only gas and charge temperature profiles with mass and energy balance method by means of dividing the kiln into segments along the axis length. ${ }^{9,10} \mathrm{CFD}$ predictions for cement rotary kilns including flame modeling, heat transfer, and clinker chemistry were also made by Mastorakos et al., ${ }^{11}$ in which a comprehensive model for most of the processes occurring in a cement rotary kiln was presented. The results showed potential improvements in the models. But only the temperature distribution was given, the gas composition distribution has not been predicted.

Notwithstanding that some significant results have been obtained in the past years, it is evident that there are many uncertainties involved in the models. None of the above theoretical models for heat transfer, clinker formation, and coal combustion are sufficient as predictive tools for rotary kiln operation. So more efforts should be made to model the dominate processes including the chemical reaction of clinker formation. It is expected that the model will be a useful tool to industry in many situations, such as the alterations in burner, fuel type, quality, quantity, etc.

In the present paper, the main work was to develop a heat flux function model that accounts for enthalpy changes of chemical reactions during clinker formation. At the same time, the particular objective is to present a comprehensive mathematical model for the cement rotary kiln, including gas-solid flow, pulverized coal combustion, and zone heat flux model for clinker formation. In terms of the commercial CFD code coupling a developed one-dimensional heat flux function model,

(12) Kolyfetis, E.; Markatos, N. C. Aerodynamics and coal-flame modelling in the burning zone of cement rotary kilns, Part 1. ZKG Int. 1996, 49 (1), 24-35.

(13) Kolyfetis, E.; Markatos, N. C. Aerodynamics and coal-flame modelling in the burning zone of cement rotary kilns, Part 2. ZKG Int. 1996, 49 (6), 326

(14) Hou, L. Y.; Fu, W. B.; Zhang Y. J. A theoretical analysis on combustion intensification for blended coal in rotary cement kiln. Fuel 2001 $80,1645-1650$. the detailed distribution of gas velocity, gas temperature, and gas components in cement rotary kiln were obtained by numerical simulation of a $3000 \mathrm{t} / \mathrm{d}$ rotary kiln with a fourchannel burner.

\section{Process Description and Mathematic Models}

Process Description of the Modern Dry Process Cement Rotary Kiln. Figure 1 shows the simplified flowchart of the cement rotary kiln system with the modern dry process. A set of cyclone preheaters is used to preheat the raw meal before it enters the precalciner where most of the $\mathrm{CaCO}_{3}$ as a component of the raw meal is decomposed. Then the raw material is fed into the rotary kiln, and a series of physical and chemical processes take place among the components of the raw material. Finally the cement clinker is formed and discharged into the cooler. About $45 \%$ of total fuel (pulverized coal in general) is injected from the burner located at the lower end of rotary kiln and then burns out to release a large amount of heat in order to meet the energy requirement of clinker formation. Primary air with the temperature of about $80^{\circ} \mathrm{C}$ is injected from the channels of the burner, and secondary air with the temperature of about $900{ }^{\circ} \mathrm{C}$ from the cooler flows into the cavity between the burner and the wall of the kiln. Heat transfer between flue gas and charge is carried out by radiation and convection. Finally the flue gas flows out of the upper end of kiln into the precalciner.

Process of Clinker Formation in a Cement Rotary Kiln. As a rule, the kiln feed precalcined in the preheater and calciner still contains a certain amount of $\mathrm{CaCO}_{3}$ that will be calcined to form $\mathrm{CaO}$ in the kiln. When kiln feed undergoes the high temperature zone in the rotary kiln, a series of chemical and mineralogical reactions occur. The components of feed (such as calcium oxide, alumina, ferric oxide, silica, and other metal oxides) interact with each other and finally form four main components of the cement clinker: $3 \mathrm{CaO} \cdot \mathrm{SiO}_{2}\left(\mathrm{C}_{3} \mathrm{~S}\right), 2 \mathrm{CaO} \cdot \mathrm{SiO}_{2}\left(\mathrm{C}_{2} \mathrm{~S}\right), 3 \mathrm{CaO} \cdot \mathrm{Al}_{2} \mathrm{O}_{3}\left(\mathrm{C}_{3} \mathrm{~A}\right)$, and $4 \mathrm{CaO} \cdot \mathrm{Al}_{2} \mathrm{O}_{3} \cdot \mathrm{Fe}_{2} \mathrm{O}_{3}\left(\mathrm{C}_{4} \mathrm{AF}\right)$. The formation temperatures of these clinker components are different. Thus, according to the temperature requirement of different components formed, the modern dry process rotary kiln can be divided into four zones, respectively (i.e., decomposed zone, transition zone (temperature increasing and exothermal reaction zone), sintering zone, and cooling zone). as shown in Figure 1.

Decomposition Zone. In the present cement process analyzed, the decomposition ratio of raw material from the outlet of the 
Table 1. Chemical Reaction Heat during Clinker Formation

\begin{tabular}{|c|c|c|c|}
\hline reaction zone & reaction temp $/{ }^{\circ} \mathrm{C}$ & main reaction & heat effect \\
\hline decomposition zone & 900 & $\mathrm{CaCO}_{3}$ decomposition & endothermal $1660 \mathrm{~kJ} / \mathrm{kg}$ of $\mathrm{CaCO}_{3}$ \\
\hline transition zone & $900-1300$ & forming $\mathrm{C}_{2} \mathrm{~S}$ & exothermal $603 \mathrm{~kJ} / \mathrm{kg}$ of $\mathrm{C}_{2} \mathrm{~S}$ \\
\hline transition zone & $900-1300$ & forming $\mathrm{C}_{4} \mathrm{AF}$ & exothermal $109 \mathrm{~kJ} / \mathrm{kg}$ of $\mathrm{C}_{4} \mathrm{AF}$ \\
\hline transition zone & $900-1300$ & forming $\mathrm{C}_{3} \mathrm{~A}$ & exothermal $37 \mathrm{~kJ} / \mathrm{kg}$ of $\mathrm{C}_{3} \mathrm{~A}$ \\
\hline sintering zone & $1300-1400$ & forming $\mathrm{C}_{3} \mathrm{~S}$ & exothermal $448 \mathrm{~kJ} / \mathrm{kg}$ of $\mathrm{C}_{3} \mathrm{~S}$ \\
\hline
\end{tabular}

precalciner is about $85-95 \%$. After it enters into the rotary kiln, the feed is heated by the gas with high temperature and the wall of kiln, and the decomposition reaction proceeds. In this zone, there are small amounts of $\mathrm{CaO} \cdot \mathrm{Al}_{2} \mathrm{O}_{3}(\mathrm{CA}), \mathrm{CaO} \cdot \mathrm{Fe}_{2} \mathrm{O}_{3}(\mathrm{CF}), 2 \mathrm{CaO}$. $\mathrm{Fe}_{2} \mathrm{O}_{3}\left(\mathrm{C}_{2} \mathrm{~F}\right)$, and $5 \mathrm{CaO} \cdot 3 \mathrm{Al}_{2} \mathrm{O}_{3}\left(\mathrm{C}_{5} \mathrm{~A}_{3}\right)$ to be formed. The main reactions are given as reactions $1-5$ :

$$
\begin{gathered}
\mathrm{CaCO}_{3} \rightarrow \mathrm{CaO}+\mathrm{CO}_{2} \quad\left(650-900{ }^{\circ} \mathrm{C}\right) \\
\mathrm{CaO}+\mathrm{Al}_{2} \mathrm{O}_{3} \rightarrow \mathrm{CaO} \cdot \mathrm{Al}_{2} \mathrm{O}_{3} \quad\left(800{ }^{\circ} \mathrm{C}\right) \\
\mathrm{CaO}+\mathrm{Fe}_{2} \mathrm{O}_{3} \rightarrow \mathrm{CaO} \cdot \mathrm{Fe}_{2} \mathrm{O}_{3} \quad\left(800^{\circ} \mathrm{C}\right) \\
\mathrm{CaO}+\mathrm{CaOFe} \mathrm{O}_{3} \rightarrow 2 \mathrm{CaO} \cdot \mathrm{Fe}_{2} \mathrm{O}_{3} \quad\left(800{ }^{\circ} \mathrm{C}\right) \\
3\left(\mathrm{CaO} \cdot \mathrm{Al}_{2} \mathrm{O}_{3}\right)+2 \mathrm{CaO} \rightarrow 5 \mathrm{CaO} \cdot 3 \mathrm{Al}_{2} \mathrm{O}_{3} \quad\left(900-950{ }^{\circ} \mathrm{C}\right)
\end{gathered}
$$

In the present work, $15 \%$ is taken as the proportion of the undecomposition $\mathrm{CaCO}_{3}$ in kiln feed, and the inlet temperature is assumed to be $850{ }^{\circ} \mathrm{C}$. Moreover, reactions $2-5$ were neglected because of a small amount of products. At the outlet of the decomposition zone, it is assumed that the complete conversion of $\mathrm{CaCO}_{3}$ was achieved, and the temperature of the kiln feed has increased up to $900{ }^{\circ} \mathrm{C}$.

Transition Zone. After the decomposition is accomplished, the temperature of the kiln feed goes up rapidly, and the reactions among the solid phase take place. Furthermore, a large amount of reaction heat is released to increase the temperature of material from $900{ }^{\circ} \mathrm{C}$ up to $1300{ }^{\circ} \mathrm{C}$. The main reactions are listed as reactions 6-8. At the outlet of the transition zone, it is assumed that $\mathrm{C}_{2} \mathrm{~S}, \mathrm{C}_{4} \mathrm{AF}$, and $\mathrm{C}_{3} \mathrm{~A}$ are completely produced; moreover, $\mathrm{C}_{2} \mathrm{~S}$ is considered to finish first and then $\mathrm{C}_{4} \mathrm{AF}$ and finally $\mathrm{C}_{3} \mathrm{~A}$.

$$
\begin{gathered}
2 \mathrm{CaO}+\mathrm{SiO}_{2} \rightarrow 2 \mathrm{CaO} \cdot \mathrm{SiO}_{2} \quad\left(1000{ }^{\circ} \mathrm{C}\right) \\
3\left(2 \mathrm{CaO} \cdot \mathrm{Fe}_{2} \mathrm{O}_{3}\right)+5 \mathrm{CaO}_{3} \cdot 3 \mathrm{Al}_{2} \mathrm{O}_{3}+\mathrm{CaO} \rightarrow \\
3\left(4 \mathrm{CaO} \cdot \mathrm{Al}_{2} \mathrm{O}_{3} \cdot \mathrm{Fe}_{2} \mathrm{O}_{3}\right) \quad\left(1200-1300{ }^{\circ} \mathrm{C}\right) \\
5 \mathrm{CaO} \cdot 3 \mathrm{Al}_{2} \mathrm{O}_{3}+4 \mathrm{CaO} \rightarrow 3\left(3 \mathrm{CaO} \cdot \mathrm{Al}_{2} \mathrm{O}_{3}\right) \quad\left(1200-1300{ }^{\circ} \mathrm{C}\right)
\end{gathered}
$$

Sintering Zone. In this zone, the formation of the liquid phase is assumed to take place above $1300{ }^{\circ} \mathrm{C}$. At the same time, the main component $\mathrm{C}_{3} \mathrm{~S}$ is formed by reaction between $\mathrm{C}_{2} \mathrm{~S}$ and free $\mathrm{CaO}$, seen in reaction 9 . Finally the clinker leaves the high-temperature zone and cools to $1300{ }^{\circ} \mathrm{C}$. The calculation is based on the

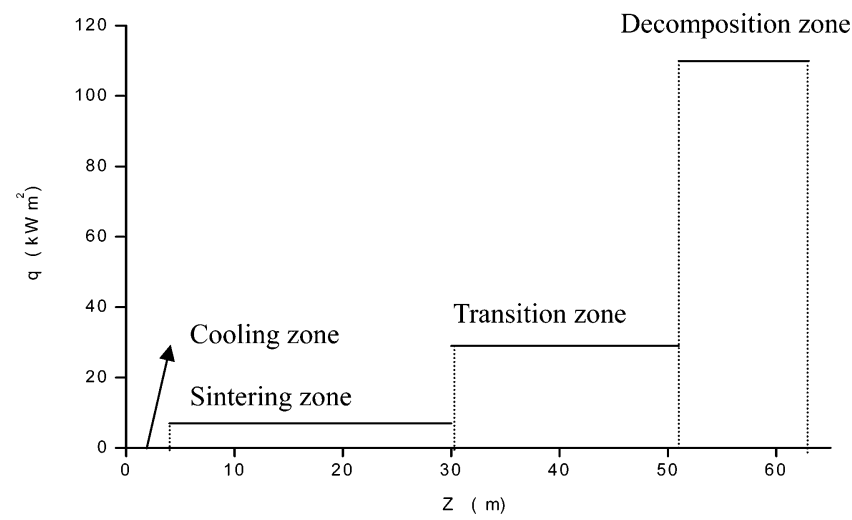

Figure 2. Zone heat flux function of clinker formation process in cement rotary kiln.

Table 2. Specific Heat of Compositions

\begin{tabular}{lccccccc}
\hline & $B_{1}$ & $B_{2}$ & $B_{3}$ & $B_{4}$ & $B_{5}$ & $B_{6}$ & $\begin{array}{c}H_{298}^{\circ}{ }^{\circ} \\
(\mathrm{kcal} / \mathrm{K} \cdot \mathrm{mol})\end{array}$ \\
\hline $\mathrm{CaO}$ & 11.86 & 0.54 & 1.66 & 0.00 & 0.00 & -4138.00 & -151.60 \\
$\mathrm{SiO}_{2}$ & 14.08 & 1.20 & 0.00 & 0.00 & 0.00 & -4445.00 & -217.70 \\
$\mathrm{Al}_{2} \mathrm{O}_{3}$ & 27.43 & 1.53 & 8.47 & 0.00 & 0.00 & -11151.00 & -400.00 \\
$\mathrm{Fe}_{2} \mathrm{O}_{3}$ & 36.00 & 0.00 & 0.00 & 0.00 & 0.00 & -11961.00 & -197.30 \\
$\mathrm{MgO}$ & 11.70 & 0.37 & 2.73 & 0.00 & 0.00 & -4435.00 & -143.70 \\
$2 \mathrm{CaO} \cdot \mathrm{SiO}_{2}$ & 27.16 & 9.80 & 0.00 & 0.00 & 0.00 & -8963.00 & -539.00 \\
$3 \mathrm{CaO} \cdot \mathrm{Al}_{2} \mathrm{O}_{3}$ & 59.96 & 3.74 & 11.80 & 0.00 & 0.00 & -22159.00 & -856.80 \\
$3 \mathrm{CaO} \cdot \mathrm{SiO}_{2}$ & 49.85 & 4.31 & 10.15 & 0.00 & 0.00 & -18643.00 & -688.10 \\
& ${ }^{a} H_{T}^{\circ}-H_{298}^{\circ}=B_{1} \mathrm{~T}+B_{2} 10^{-3} T^{2}+B_{3} 10^{5} T^{-1}+B_{4} 10^{-6} T^{3}+B_{5} 10^{8} T^{-2}$ \\
$+B_{6}$. Unit: kcal/K$\cdot \mathrm{mol}$.
\end{tabular}

assumption that the amount of the liquid phase in this zone is about $20-30 \%$ and the free $\mathrm{CaO}$ is completely combined to form $\mathrm{C}_{3} \mathrm{~S}$.

$$
2 \mathrm{CaO} \cdot \mathrm{SiO}_{2}+\mathrm{CaO} \rightarrow 3 \mathrm{CaO} \cdot \mathrm{SiO}_{2} \quad\left(1350-1450{ }^{\circ} \mathrm{C}\right)
$$

Cooling Zone. In the dry process cement rotary kiln, the work of the clinker cooling was finished mainly in the cooler. Therefore, the cooling zone in the kiln is very short. In the present paper, the function of cooling is neglected in this zone, and the heat flux is supposed to be zero in the cooling zone.

On the basis of process analysis described above and the experiences of design and operation, the proportion of four zones (decomposition zone, transition zone, sintering zone, and cooling zone) in length is considered as 18:35:41:6 (see Figure 1). Thus, the heat fluxes (Figure 2) are obtained by calculating the enthalpy change during the chemical and physical processes in every zone. The formation heats of the chemical reactions are given in Table 1 , and the specific heats of the compositions are listed in Table 2.

A user-defined function (UDF) is a function that you program that can be dynamically loaded with the FLUENT solver to enhance the standard features of the code. UDFs are written in the $\mathrm{C}$ programming language. In the present work, at first, these heat flux functions of each zone are written as the UDF file in the $\mathrm{C}$ programming language, then the UDF files are executed as interpreted functions in FLUENT. Thus, values can be passed to the solver by a UDF or returned by the solver to a UDF. In practice, the UDF file was called the wall thermal boundary conditions in FLUENT.

Mathematic Models. The flow in a rotary kiln is a typical kind of gas-solid turbulent flow with chemical reactions. The models for the rotary kiln consist of RNG $k-\epsilon$ turbulent model for gas phase and particle stochastic trajectory model for solid-phase coupled with volatile combustion and char heterogeneous combustion.

Gas Phase. The steady-state continuity equation of gas phase is written as eq 10. The source term $S_{\mathrm{p}}$ resulted from combustion particles. The components of velocity in coordinate direction $x, y$, and $z$ are given in eq 11, which include pressure, gravitational force (buoyancy effects), and the source term arising from interaction between gas and solid:

$$
\begin{gathered}
\frac{\partial}{\partial x_{i}}\left(\rho u_{i}\right)=S_{\mathrm{p}} \\
\frac{\partial}{\partial x_{j}}\left(\rho u_{i} u_{j}\right)=-\frac{\partial p}{\partial x_{i}}+\frac{\partial \tau_{i j}}{\partial c_{j}}+\rho g_{i}+F_{i}+S_{\mathrm{p}}
\end{gathered}
$$

The RNG $k-\epsilon$ turbulence model is derived from the instantaneous Navier-Stokes equations, using a mathematical technique 
called "renormalization group" (RNG) methods. ${ }^{15,16}$ The analytical derivation results in a model with constants different from those in the standard $k-\epsilon$ model and additional terms and functions in the transport equations for $k$ and $\epsilon$. The transport equations for the RNG $k-\epsilon$ model are given in eqs 12 and eq 13:

$$
\begin{gathered}
\frac{\partial}{\partial x_{i}}\left(\rho k u_{i}\right)=\frac{\partial}{\partial x_{j}}\left(\alpha_{k} \mu_{\mathrm{eff}} \frac{\partial k}{\partial x_{j}}\right)+G_{\mathrm{k}}+G_{\mathrm{b}}-\rho \epsilon \\
\frac{\partial}{\partial x_{i}}\left(\rho \epsilon u_{i}\right)=\frac{\partial}{\partial x_{j}}\left(\alpha_{\epsilon} u_{\mathrm{eff}} \frac{\partial \epsilon}{\partial x_{j}}\right)+C_{1} \frac{\epsilon}{k}\left(G_{\mathrm{k}}+C_{3} G_{\mathrm{b}}\right)-C_{2} \rho \frac{\epsilon^{2}}{k}-R_{\epsilon}
\end{gathered}
$$

In eqs 12 and $13, G_{\mathrm{k}}$ represents the generation of turbulence kinetic energy due to the mean velocity gradients. $G_{\mathrm{b}}$ is the generation of turbulence kinetic energy due to buoyancy. The quantities $\alpha_{k}$ and $\alpha_{\epsilon}$ are the inverse effective Prandtl numbers for $k$ and $\epsilon$, respectively.

The energy equation solves for enthalpy, seen in eq 14. The source term $S_{\mathrm{h}}$ in the energy equation includes combustion and radiation heat transfer rates:

$$
\frac{\partial}{\partial x_{i}}\left(\rho v_{i} h\right)=\frac{\partial}{\partial x_{i}}\left(\Gamma_{\mathrm{h}} \frac{\partial h}{\partial x_{i}}\right)+S_{\mathrm{h}}
$$

The temperature in the rotary kiln is high, and radiation heat transfer is dominant. In the present work, the heat radiation is described by the P-N model, ${ }^{17}$ which is based on the expansion of the radiation intensity $I$ into an orthogonal series of spherical harmonics. The expression for $-\nabla q_{\mathrm{r}}$ can be directly substituted into the energy equation to account for heat sources due to radiation as seen from eq 15:

$$
-\nabla q_{\mathrm{r}}=a G-4 a \sigma T^{4}
$$

The mixture fraction model was developed to simulate the coal combustion. ${ }^{18,19}$ The mixture fraction model is based on the solution of transport equations for one or two conserved scalars (the mixture fraction and/or its variance). The chemistry is modeled by the equilibrium model, which assumes that the chemistry is rapid enough for the chemical equilibrium to exist at the molecular level. It computes species from the mixture fraction by an algorithm based on the minimization of Gibbs free energy. Individual component concentrations for the species of interest are derived from the predicted mixture fraction distribution. The mixture fraction model can account for the interaction of turbulence and chemistry. In nonpremixed combustion, the distribution of gas components and temperature can be obtained by solving the mixture fraction and its variance transfer equations, given in eqs 16 and 17 :

$$
\begin{gathered}
\nabla \cdot(\rho \bar{v} \bar{f})=\nabla \cdot\left(\frac{\mu_{t}}{\sigma_{t}} \nabla \bar{f}\right)+S_{\mathrm{m}} \\
\nabla \cdot\left(\rho \bar{v} \overline{f^{2}}\right)=\nabla \cdot\left(\frac{\mu_{t}}{\sigma_{t}} \overline{f^{2}}\right)+C_{\mathrm{g}} \mu_{t}\left(\nabla^{2} f\right)-C_{\mathrm{d}} \rho \frac{\epsilon}{k} \overline{f^{\prime 2}}
\end{gathered}
$$

Particle Phase. The particle phase is treated by solving the Lagrangian equations for the trajectory of a statistically significant sample of individual particle, which represents a number of the real particles with the same properties. In present work, coal particles following a Rossin-Rammler size distribution are tracked

(15) Chen, Q. G.; Xu, Z.; Zhang, Y. J. Application of two versions of a RNG based $k-\epsilon$ model to numerical simulations of turbulent impinging jet flow. J. Hydrodyn. 2003, 15 (2), 71-76.

(16) Kuang, C. P. Recirculating flow in shallow open channel via the RNG $k-\epsilon$ model. J. Hydrodyn. 1999, 11 (1), 41-49.

(17) Siegel, R.; Howell, J. R. Thermal Radiation Heat Transfer; Hemisphere Publishing Corporation: Washington, DC, 1992.

(18) Smoot, L. D.; Smith, P. J. Coal Combustion and Gasification; Plenum Press: New York, 1985.

\begin{tabular}{|c|c|c|c|c|c|c|c|c|c|}
\hline \multicolumn{4}{|c|}{ proximate analysis \%(ad) } & \multicolumn{5}{|c|}{ ultimate analysis \%(ad) } & \multirow{2}{*}{$\frac{Q_{\text {dw.ad }}}{\mathrm{MJ} / \mathrm{kg}}$} \\
\hline M & $\mathrm{V}$ & $\mathrm{C}$ & A & $\mathrm{C}$ & $\mathrm{H}$ & $\mathrm{O}$ & & $S$ & \\
\hline & 22 & 53 & 20 & 39.3 & 5.0 & 34 & 1.5 & 08 & 253 \\
\hline
\end{tabular}

(19) Huang, L.; Lu, J. D.; Xia, F. 3-D mathematical modeling of an inline swirl-spray precalciner. Chem. Eng. Process. 2006, 45 (3), 204-213.
Table 3. Operation Parameter of Four-Channel Coal Burner

\begin{tabular}{cccccc}
\hline & \multicolumn{4}{c}{ primary air } & proportion of \\
\cline { 2 - 5 } parameter & center air & coal air & swirl air & axis air & primary air \\
\hline velocity $(\mathrm{m} / \mathrm{s})$ & 60 & 23 & 164 & 200 & 14.7
\end{tabular}

Table 4. Proximate Analysis and Ultimate Analyses of Coal

using stochastic trajectories model, ${ }^{20,21}$ and gravity effect is taken into account, as seen in eq 18:

$$
M_{\mathrm{p}} \frac{\mathrm{d} u_{i \mathrm{p}}}{\mathrm{d} t}=C_{\mathrm{D}} \rho_{\mathrm{g}}\left(\frac{A_{\mathrm{p}}}{2}\right)\left(u_{i \mathrm{~g}}-u_{i \mathrm{p}}\right)\left|u_{i \mathrm{~g}}-u_{i \mathrm{p}}\right|+M_{\mathrm{p}} g_{\mathrm{k}}
$$

Combustion processes of coal are treated as devolatilizing first and then char burning. Devolatilization is according to a two-reaction model (eqs 19 and 20), and combustion of volatile is taken as infinitely fast. ${ }^{22}$ The devolatilization rate constant is expressed as eqs 21 and 22, where competing rates may control the devolatilization over different temperature ranges. The model requires input of the kinetic rate parameters $\left(A_{1}, E_{1}, A_{2}\right.$, and $\left.E_{2}\right)$ and the yields of the two competing reactions $\left(\alpha_{1}\right.$ and $\left.\alpha_{2}\right)$. It is recommended that $\alpha_{1}$ be set to the fraction of volatiles determined by proximate analysis since this rate represents devolatilization at low temperature. The second yield parameter $\left(\alpha_{2}\right)$ should be set close to unity, which is the yield of volatiles at very high temperature:

$$
\begin{gathered}
\left.(\text { raw coal }) \stackrel{k_{1}}{\rightarrow}\left(1-\alpha_{1}\right)(\text { char })+\alpha_{1} \text { (volatiles }\right) \\
\left.(\text { raw coal }) \stackrel{k_{2}}{\rightarrow}\left(1-\alpha_{2}\right)(\text { char })+\alpha_{2} \text { (volatiles }\right) \\
k_{1}=A_{1} \exp \left(\frac{-E_{1}}{R T_{\mathrm{av}}}\right) \\
k_{2}=A_{2} \exp \left(\frac{-E_{2}}{R T_{\mathrm{av}}}\right)
\end{gathered}
$$

The shrink core model is used to describe the char burning, and the rate is controlled by chemical reaction and oxygen diffusion, ${ }^{23}$ given in eq 23:

$$
\frac{\mathrm{d} M_{\mathrm{p}}}{\mathrm{d} t}=-A_{\mathrm{p}} P_{\mathrm{ox}} \frac{D_{0} k}{D_{0}+k}
$$

where $A_{\mathrm{p}}$ is the surface area of the droplet $\left(\pi d^{2}\right), P_{\mathrm{ox}}$ is the partial pressure of oxidant species in the gas surrounding the combusting particle, and the kinetic rate incorporates the effects of chemical reaction on the internal surface of the char particle (intrinsic reaction) and pore diffusion.

\section{Prediction Conditions}

The predicted case is a in-line rotary kiln $63 \mathrm{~m}$ in length and $4.3 \mathrm{~m}$ in diameter. The average daily production capacity is $3000 \mathrm{t}$ of clinker. A typical four-channel burner is used in kiln.

(20) Fan, J. R.; Zhang, X. Y.; Chen L. H.; Cen, K. F. New stochastic particle dispersion modeling of a turbulent particle-laden round jet. Chem. Eng. J. 1997, 66, 207-215.

(21) Ghenai, C.; Lin, C. X.; Ebadian, M. A. Numerical investigation of oxygen-enriched pulverized coal combustion. Proc. 2003 ASME Summer Heat Transfer Conf. 2, 57-62.

(22) Jamaluddin, A. S.; Truelove, J. S.; Wall, T. F. Modeling of coal devolatilization and its effects on combustion calculations. Combust. Flame 1985, 62, 85-89.

(23) Smoot, L. D. Modeling of coal combustion processes. Prog. Energy Combust. Sci. 1984, 10 (22), 229-254. 
Table 5. Composition of Raw Material (\%)

\begin{tabular}{ccccccccccc}
\hline sample & $\mathrm{LOI}^{a}$ & $\mathrm{SiO}_{2}$ & $\mathrm{Al}_{2} \mathrm{O}_{3}+\mathrm{TiO}_{2}$ & $\mathrm{Fe}_{2} \mathrm{O}_{3}$ & $\mathrm{CaO}$ & $\mathrm{MgO}$ & $\mathrm{K}_{2} \mathrm{O}$ & $\mathrm{Na}_{2} \mathrm{O}$ & $\mathrm{SO}_{3}$ & $\mathrm{Cl}$ \\
\hline raw meal & 34.50 & 14.59 & 3.55 & 2.20 & 43.47 & 0.88 & 0.32 & 0.05 & 0.18 & 0.006
\end{tabular}

${ }^{a}$ LOI is loss of ignition.

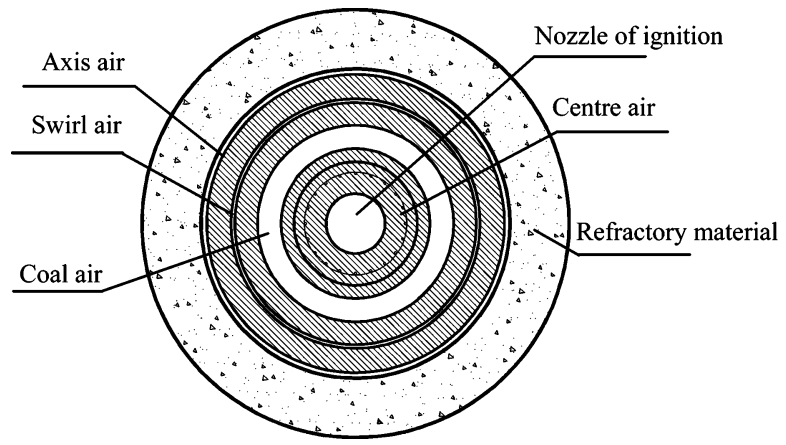

Figure 3. End face of four-channel burner.

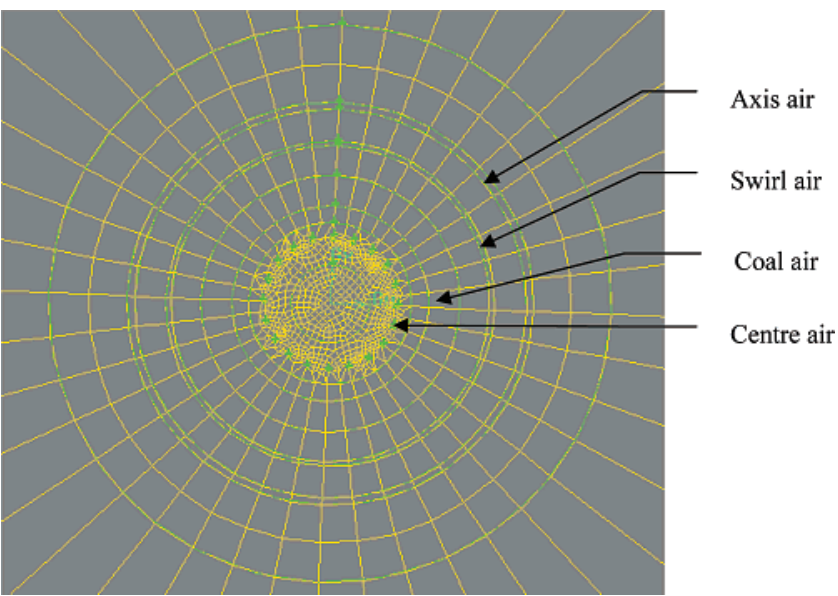

Figure 4. Grid cross-section of four-chanel burner.

The primary air is divided into axis, swirl, coal, and center ones. The end cross-section of the burner is shown in Figure 3. The velocities of every channel are given in Table 3 . The proximate and ultimate analyses of coal are listed in Table 4. The raw material compositions are given in Table 5.

The discretization scheme for the convection terms of each governing equation is very important. In present work, the flow equation, turbulence equation, energy equation, and mixture fraction equations were all discretizded by the first-order upwind scheme. ${ }^{24,25}$ This prevents the oscilation behavior of converged solutions. Convergence is easier to achieve than for higher order schemes; however, significant false diffusion occurs. Secondorder schemes can achieve higher accuracy and produce finer details of the solution but generally suffer from deteriorating convergence when applied to complex flow fields and geometries. Because of the complexity of the current problem and the major difficulty to couple heat flux functions, the first-order upwind scheme (higher numerical stability) was adopted.

The distribution of grid cells was presented in Figures 4 and 5 , which showed grid cross-section of the four-channel burner and the full rotary kiln grid, respectively. To optimize convergence and computing time, the grid is finer at the burner area and coarser at the secondary air inlet and exhaust gas outlet.

(24) Zhao, X.; Richards, P. G.; Zhang, S. J. High-resolution schemes for bubbling flow computation. Appl. Math. Modell. 2005, 29, 1232-1251.

(25) Patel, M. K.; Markatos, N. C. Evaluation of eight discretization schemes for two-dimensional convection-diffusion equations. Int. J. Numer. Methods Fluids 1986, 6 (3), 129-154.

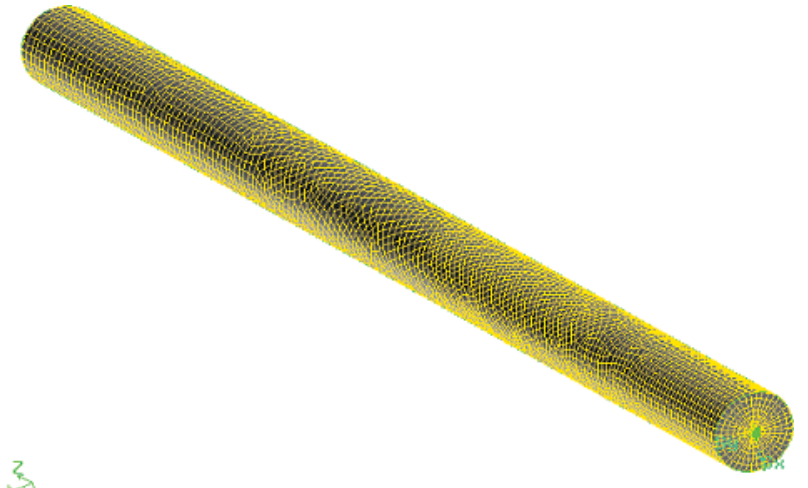

Figure 5. Rotary kiln grid.

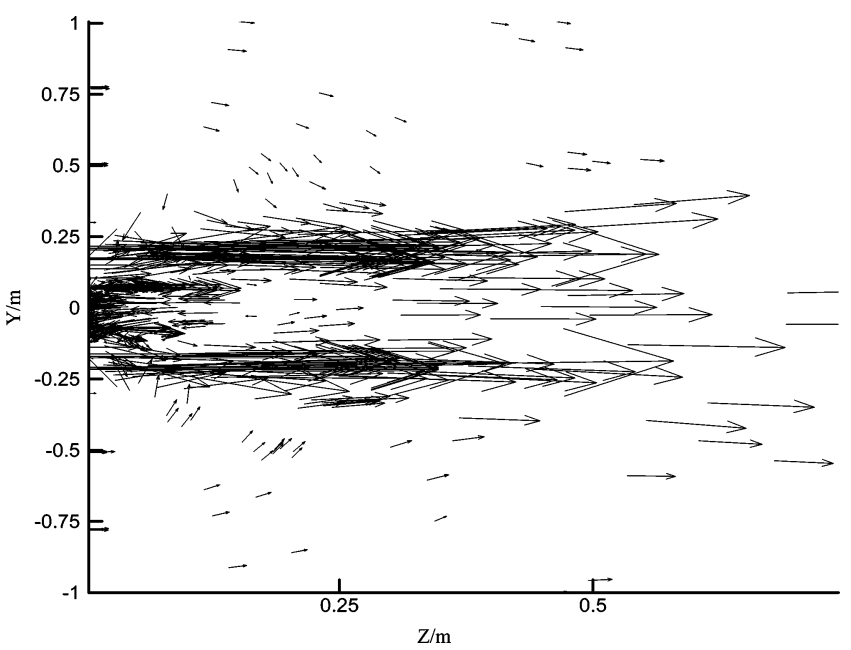

Figure 6. Axis velocity vector in the near-burner region $(\mathrm{m} / \mathrm{s})$.

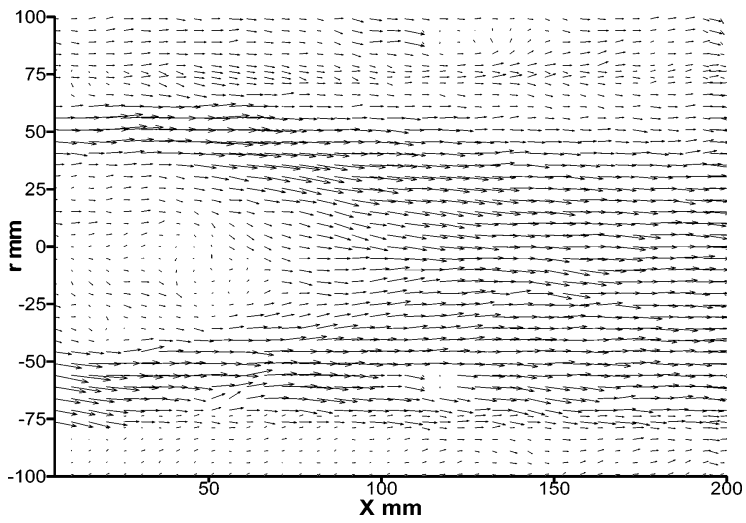

Figure 7. Axis velocity vector by PIV measure in the near-burner region.

The total number of 96504 mixed cells comprising tetrahedron, pentahedron, and hexahedron was obtained. Testing with finer grids indicated that the results obtained are virtually grid independent. In general, a fully converged run, using the above grid, required about 3500-step iteration. Computing times for this run are about $15 \mathrm{~h}$ using a $1.7 \mathrm{GHz}$ Pentium IV processor and $256 \mathrm{M}$ memory. To avoid the high fluctuation and divergent behavior, under-relaxation factors for pressure, momentum, energy, $k$, and $\epsilon$ were reduced to $0.5,0.5,0.6,0.6$, and 0.6 . It 


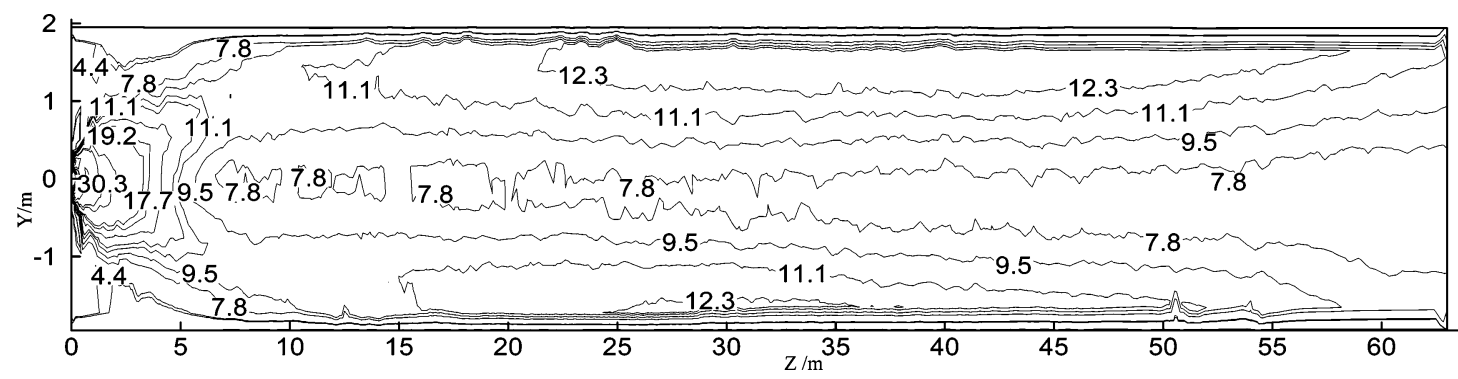

Figure 8. Axis velocity contour of cross-section along rotary kiln $(\mathrm{m} / \mathrm{s})$.

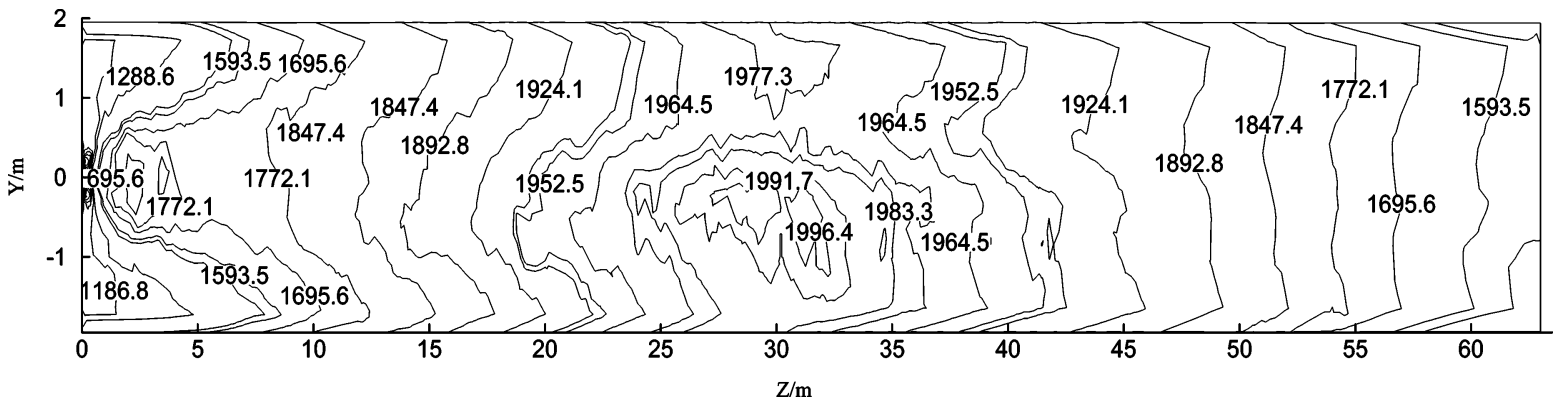

Figure 9. Axis temperature contour of cross-section along rotary kiln (K).

is a good practice to begin a calculation using the default underrelaxation factors. If the residuals continue to increase, the number of under-relaxation factors should be reduced. For the level of accuracy, the limited residual value for a convergence run reaches $10^{-4}$ for all equations.

In addition, the modeling of processes in a rotary kiln is based on following hypothesis:

(1) Rotating of kiln and moving of kiln feed are neglected.

(2) Packing volume of kiln feed is neglected.

(3) Process investigated is considered to be steady state.

(4) Heat flux in every zone is supposed to be uniform.

(5) $\mathrm{CO}_{2}$ produced in decomposition zone is neglected.

\section{Results and Discussion}

Figure 6 shows the axis velocity vectors in the near-burner region. As can be seen from Figure 6, there exists a hightemperature recirculation zone in flue gas close to the outlet of the center channel of the burner. It is also evident that there exists an entrainment phenomena (i.e., high-temperature secondary air is entrained by high-speed primary air in near-burner region). The reason is that a strong swirl air of the typical fourchannel burner can create a stronger swirl effect. In addition, the velocity of axis air of the primary air is much higher than that of the secondary air, which results in a large speed difference. These phenomena are a benefit to the ignition of coal and the stabilization of pulverized coal combustion. To validate the phenomena of flow close to the outlet of burner, the burner is made on the scale of 1:5, and a cold test of the flow field of the burner is carried out. Figure 7 shows the axis velocity vector by PIV (particle image velocimetry) in the nearburner region. Recirculation and entrainment phenomena can also be found in the near-burner region. Figure 8 shows the axis velocity contour of a cross-section along the rotary kiln. It can be seen from Figure 8 that the velocity of primary air (especially swirl air and axis air) is rather high and that the velocity of secondary air is lower in the outlet zone of burner; however, the velocity of secondary air gradually increases because of the entrainment effect of primary air. The distribution of flow velocity comes to stability after the position at $10 \mathrm{~m}$ along the rotary kiln.

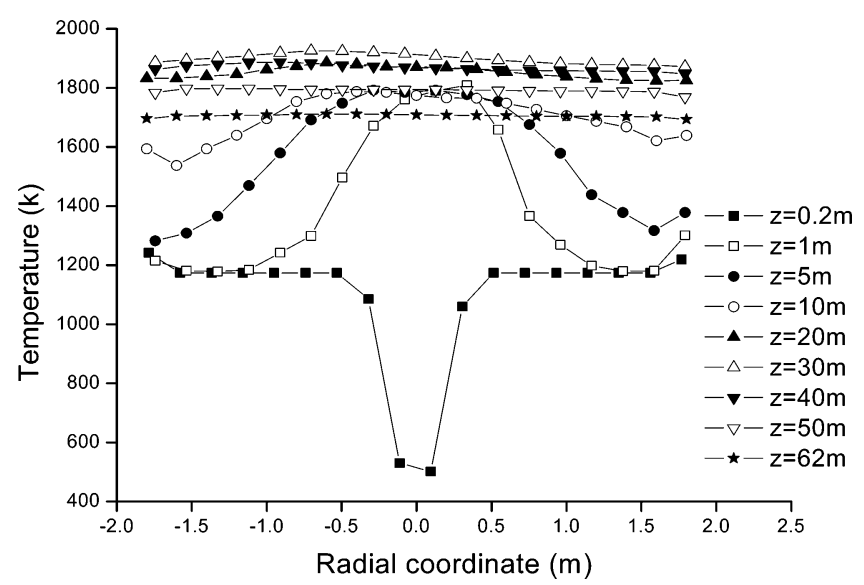

Figure 10. Radial profiles of the gas temperature at various locations along the kiln.

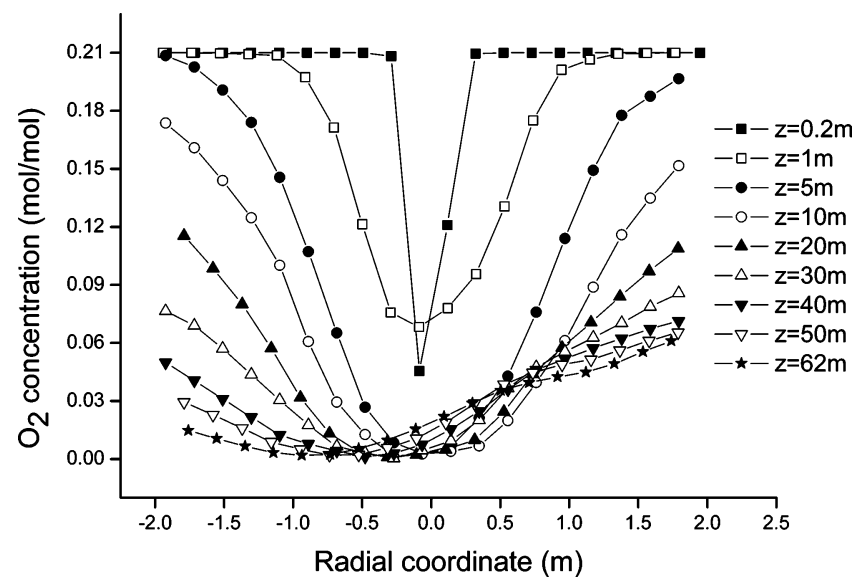

Figure 11. Radial profiles of $\mathrm{O}_{2}$ concentration at various locations along the kiln.

Figures 9 and 10 show the cross-section contour and radial profile of gas temperature along the rotary kiln, respectively. The temperature of secondary air originating from the preheated air is very high in the cement product process. Thus it reduces the energy loss dragged by high-temperature gas and increases the energy efficiency of the kiln. It can be seen that pulverized 


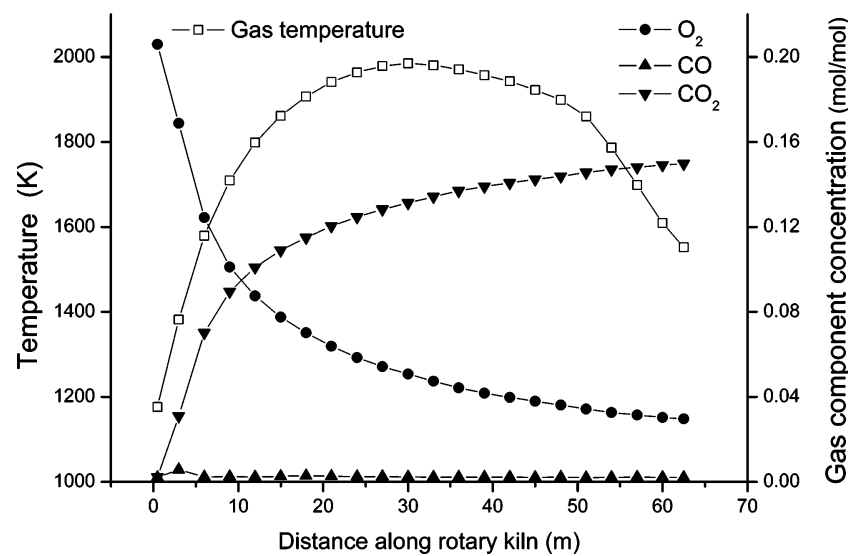

Figure 12. Average curves of cross-section along the kiln.

coal ignites immediately and burns about $0.2 \mathrm{~m}$ after injection. The temperature in the zone of burner outlet rises up rapidly. It is easy to find that there occurs a local high-temperature region at the center zone from 1 to $5 \mathrm{~m}$ along the rotary kiln, as shown in Figure 10. For the clinker formation process, the flame must not only keep proper length but also reach necessary temperature. With the most of the pulverized coal burning out and releasing a large amount of heat, the maximum gas temperature (about $2000 \mathrm{~K}$ ) is achieved at about $30 \mathrm{~m}$ downstream. Figure 9 shows that a high-temperature zone is located between 20 and $45 \mathrm{~m}$ from the burner. Gas temperature deceases because raw material absorbs the heat from the gas radiation and convection close to the inlet of the kiln feed. Radial profiles of gas temperature (Figure 10) show that there is significant nonuniformity of the temperature that, however, diminishes downstream with the exit profile becoming essentially flat.

Figure 11 gives the radial profiles of $\mathrm{O}_{2}$ concentration at various locations along the kiln, and Figure 12 shows the average curves of the cross-section along the rotary kiln. At the ignition zone, component $\mathrm{O}_{2}$ is consumed rapidly. With the pulverized coal diffusing from center to near wall of kiln, secondary air supplies enough $\mathrm{O}_{2}$ to coke burning out. From these figures, it can be seen that the concentration of $\mathrm{O}_{2}$ near the upper wall of the kiln is higher than that at the lower part. The reason is that coal particles pass gradually off-axis and decline due to gravity effect. In addition, it can be inferred that the combustion rate is very high $10 \mathrm{~m}$ ahead of the burner because a large amount of volatiles combust in this zone (Figures 11 and 12) and residual coke and $\mathrm{CO}$ come to combust completely between 10 and $45 \mathrm{~m}$. As is shown in Figure 12, the average $\mathrm{O}_{2}$ concentration of cross-section is $3 \%$; the average $\mathrm{CO}$ and $\mathrm{CO}_{2}$ concentration is $0.2 \%$ and $15 \%$, respectively; and the burnout ratio reaches $97 \%$ at the inlet of the kiln feed.

\section{Conclusions}

The combustion process of coal under industrial operation conditions has been modeled with the comprehensive model for a cement rotary kiln in the dry process cement product system. The major work lies in the analysis and summarization of physical and chemical processes in the kiln. On this basis, a heat flux function model accounting for the energy change of clinker formation to solve the heat transfer between gas and material was presented. A commercial 3D CFD code (FLUENT) coupling a one-dimensional heat flux function model is carried out to model and investigate the behavior of combustion using the four-channel burner in the rotary kiln. The overall behavior here provides a means to know the behaviors of burner, fuel, etc. for an industrial kiln.

Acknowledgment. The authors are grateful for the support provided by the National High Technology Research and Development 863 Program of the People's Republic of China (2002AA529150) and the cooperation with the Tianjin Cement Industrial Design and Research Institute of the People's Republic of China.

EF060027P 